\title{
ROLE OF NGO IN FILLING THE GAP OF GOVERNMENT \\ (A Case Study of Indus Resource Centre khairpur, Sindh Pakistan)
}

\author{
Muhammad SalehMemon \\ Assistant Professor, Business Administration, Shah Abdul Latif University Khairpur Pakistan \\ saleh.memon@salu.edu.pk \\ NasreenAnisGoraya \\ MS student, Business Administration, Shah Abdul Latif University Khairpur Pakistan \\ Nasreen_Goraya@hotmail.com \\ Bushra Fatima Ansari \\ MS student, Business Administration, Shah Abdul Latif University Khairpur Pakistan \\ bushrafatima.ansari@yahoo.com
}

\begin{abstract}
Role of non- government organization in filling the gap of government was studied through a study conducted on Indus Resource Centre. Government gap is created when some areas are being deprived of Government efforts. The objectives of research were firstly; to analyze the role of IRC in filling the gap of Government and to find out at what extend IRC is effective in fulfilling the needs of rural people. Data was taken from the majority of beneficiaries of the IRC and it was analyzed through the exploratory factor analysis technique with the help of SPSS 16. The overall analysis of study reveals that IRC plays very important role in filling the gap and it is very effective in fulfilling the needs of rural people by providing education facilities, human right awareness, sustainable livelihood, health and disaster management.
\end{abstract}

Keywords: Rural Development, Government gap, education facilities, human right awareness, sustainable livelihood, health and disaster management.

\section{Council for Innovative Research}

Peer Review Research Publishing System

Journal: INTERNATION JOURNAL OF COMPUTERS AND TECHNOLOGY

Vol. 13, No. 5

editorijctonline@gmail.com

www.cirworld.org/journals 


\section{Introduction}

Pakistan has more population in rural area as compared with the urban areas. There is huge inequality of development status between urban areas and rural areas. The term development is very composite and contented (Lewis \& Kanji, 2009).It indicates that development has no single definition. World leaders have followed Millennium Development Goals (MDGs) in term of reducing poverty and hunger, toaccomplishuniversal primary education, boosting gender equality, eradicating child mortality, meliorating maternal health, combating diseases such as HIV/AIDS and malaria, assuring environmental sustainability and uprising global partnerships for action (Willis, 2005).

Pakistan Government is working for achieving these MDGs goals. But it does not cover whole country. As a result some areas of Pakistan are being deprived of government efforts. The Nongovernmental organizations are serving as major development actors in Pakistan because these are filling the gap where government is unable to meet its obligations. (Ulleberg, 2009-10). NGO role is not to supervene government but it only facilitates role of the government towards the development.

Now a day's everyone knows about the nongovernment organization but they have been present since Pakistan was established. Many of NGOs provided the services of rehabilitation, health and education during the first few weeks of Pakistan. (Tufail, 2006).

Poverty in rural sindh is double as of urban areas. About $48.63 \%$ of rural population of sindh is suffering from absolute poverty ${ }^{1}$. (Talat, Quershi, \& Ali, 2004).NGOs in sindh are playing very important role in changing the conditions of people.

The research paper focuses on the role of Indus resource centrekhairpur Pakistan for enhancing the development of rural areas of khairpur. Indus resource centre (IRC) is contributing directly or indirectly for the achievements of MDGs.

\section{The objectives of this paper are:}

1. How IRC plays its role in filling the government gap ${ }^{2}$ ?

2. To what extend IRC is effective in fulfilling the needs of rural people?

\section{Literature Review}

(Mudimu \& Bernisten, 1987)stated that at national and international level the food deficit not often spread until and unless a extensively food hungers prevail and in starting the prior victims are household and villages.

(Fowler, 1988)described in his research that NGO's have two main functions, they raise the voice of general public and also safeguard the rights of human. Researchers concluded that NGO's work more efficiently as compare to Government bodies.

(Obot, 1989) discussed in his research that rural development progress can be easily examine by the help of quality of education, health care services, communication channels(roads), basic necessities (Water, availability of food, housing)

The areas that permit any NGO's in any location to perform their services is not the responsibility of private bodies but it is the prime duty of state to perform for well being of society. (Bratton, 1989)

(Streeten, 1997)mentioned that NGO's are that type of organization which are engaged in to decrease the humans trouble and to promote the living standard of poor communities.

(Grandvaux, welmond, \& wolf, 2002)had noticed that throughout the previous period of ten years NGO's working for the improvements of economy. NGO's play their role to remove poverty, enhance well being of society and also in sector of education. Many NGO's plays very vital role in education in most of the countries of the Africa with the help of funds provider. Researcher basically focus on four points to examine the NGO's influence in education sector (a) connection between NGO's and government bodies (b) NGO's act in policies of education (c)connection between NGO's and funds providers (d) Effect of NGO's on social community. For getting the information researcher made a case study of four countries Guinea, Malawi, Mali and Ethiopia. By collecting the secondary data and also primary data by conducting interviews of different players of education sector they conclude that NGO's must make the interaction of government to get the desire effect, combination of NGO's and government bodies are very important for getting education goals.NGO's can complete the task to influence the future course of action to get the fruitful result. The relationship between NGO's and funds provider is twisted; both parties want to achieve same target quality of education.NGO's are not only intermediary to perform the plan of donor or govt: but they have the quality to innovate the society.

(Desai, 2005)stated NGO's perform vital role for the enhancement of society development. Sheconducted survey on some actions performed by NGO's for the enhancement of wellbeing of people by giving awareness regarding their rights , by

\footnotetext{
${ }^{1}$ Absolute poverty is "a condition that is characterized by severe deprivation of food, safe drinking water, sanitation facilities, health, shelter, education and information. It depends both on income and assess to resources."

${ }^{2}$ Gap is space which is created when the difference exists between the availabilities of resources and the requirements of those resources.
} 
supporting through short term loans ,by the help of these services community is able to utilize their skills and become independent.

(Lewis \& Kanji, Non-Governmental organization and development, 2009)examined that NGO's are not only involves in transferring the resources from one party to another but also responsible for generating ideas and method to improve the way of development and to motivate the public for development of their country.

(Nikkah \& Redzuan, 2010)researched on part played by NGO's in achieving the economic development. They stated that by the help of micro financing NGO's gave power to community in order to generate their own income, so that the community only depend on their own resources and by this step NGO's play a vital role towards the development of economy.

(Seidemann, 2011)researched to find out the function of NGO's in the area of agriculture advancement in sub-saharan Africa.Researcher found that in early period of time NGO's in sub-saharan Africa not plat their role for the development of agriculture sector reason behind is that some time not active donors and some timeNGO's features not match with this field but now a days. NGO's play two main role: to give out the different type of services like information regarding the rights of land ,research results and verbal support towards their rights. Researcher also suggested that NGO's can also support the small farmer department by giving them relevent information like awareness regarding legal advice,duties of account etc. They can also provide the information regarding loaning facility,insurance for their safetyside and to connect these type of bodies with local farmers to enhance the growth of agriculture.

Mostly the developments of rural areas depend upon agriculture, health. Industry and human resource development. Mostly people think that NGO's are play vital role in rural development .Researcher's purpose of study is to examine the performance of NGO's in enhancing the agriculture, health activities and also focus that how much NGO's increase the knowledge regarding to raise the awareness of development opprtunities. Researcher use primary data collection method by different number of sample of beneficiaries, non-beneficiaries and govt: bodies. Conclude that NGO's have very effective role in the development of rural areas by upgrading the govt: policies and programs in different sector like in education,agriculture,community development and poverty alleviation. (Enyioko, 2012)

(Chitongo, july 2013) stated that many steps were taken to achieve the target to remove poverty especially in those countries which are developing. Researcher focused on the action of main instance applied by Catholic Relief services through protecting vulnerable livelihood programme(pvlp).Researcher worked in Murewa district Zimbabwe by adopting quantitative and qualitative method.researcher conclude that the main livelihood occuption in Murewa District is agriculture and the main problem for this is low rainfall, ha stated that there is a requirement for proper water system for the growth of society. Mostly people face the food shortage because they are not in a position to cultivate the enough grain. Researcher conclude that NGO's play very impressive role in this area,mostly people are beneficiaries of PVL programme. Now other communities are also working there for the developing purpose.Researcher suggest that the voice of these people must be raised in order to more funding from govt: and development partners.

(Kanipakam, 2014)described that the term NGOs is not unfamiliar in the India because many NGOs are working for the rural development of India. Rural development which involves the stability of economy, enhancement of living standard of the people of rural areas by giving them sufficient and excellent degree of social services. Researcher studies focus on the essential role of NGOs for getting the target of economic stability.After her research she found that the development of rural areas also depend on the share of rural people in terms of their effort because they are more familiar with their language, culture and tradition. Researcher believes that until and unless village council not active in the way of development they can't get the better condition of their economy.

\section{Conceptual Research Model}

The role of IRC in filling the gap of Government is visualized through the model. The IRC provides education, health facilities, sustainable livelihood, awareness of human rights and disaster management programs to those people who are ignored by Government. 


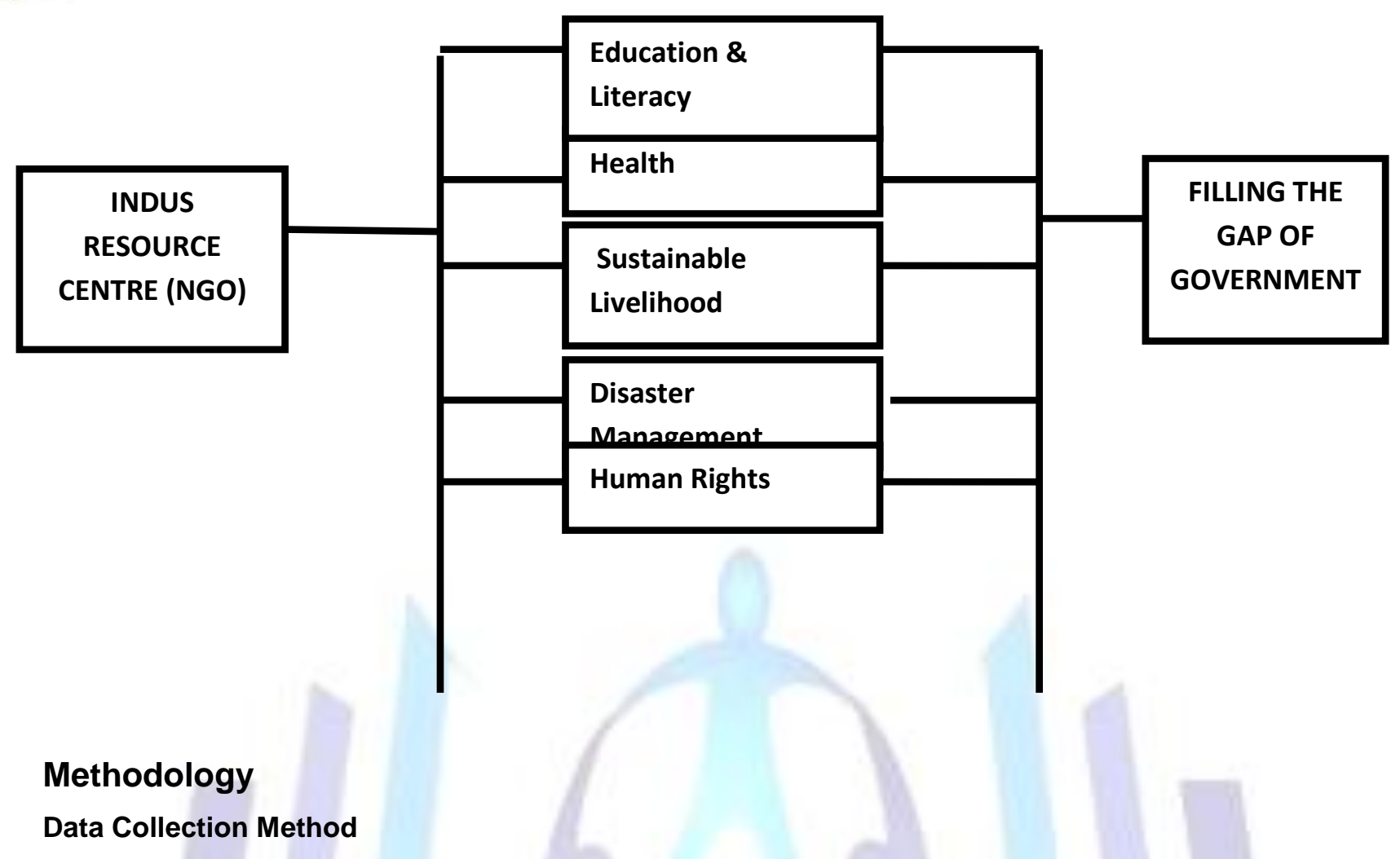

Data was collected through the primary source. It encourages direct participation of the respondents by filling out questionnaires or by interacting with an interviewee (zikmund, 2000).In this research; questionnaires were designed for gathering the relevant information from the beneficiaries of Indus resource centrekhairpur Pakistan.

\section{Data Analysis Technique}

Exploratory Factor Analysis technique was used through SPSS 16. It is used to reduce data or variables in the components in order to examine the percentage of variance contributed by each component. In exploratory factor analysis, scree plot and total variance explained were used.

\section{Result and Discussion}

\section{Scree Plot}

The scree plot is a graph which is useful for determining how many components to retain. It is graph of the eigenvalues against all the factors. Graph shows, the point from where curve goes flatten is neglected because it shows components 6 to 18 are of less importance, so only 5 components have been retained

\section{Total Variance Explained}

Total variance is used to determine percentage of each component in total variance and cumulative Scree Plot percentage of all components. Table 1 tells about the contribution of five components of IRC in filling the gap of Government.

\section{TOTAL VARIANCE EXPLAINED}

\begin{tabular}{|l|l|l|l|l|}
\hline S.\# & Component & Total & \% of variance & Cumulative \% \\
\hline 1 & Human Rights and Sojhro School Project & 2.248 & 33.190 & 33.190 \\
\hline 2 & Sustainable Livelihood & .943 & 13.929 & 47.119 \\
\hline 3 & Girls Education \& Literacy & .796 & 11.751 & 58.870 \\
\hline 4 & Disaster Management & .474 & 7.004 & 65.874 \\
\hline 5 & Health & .466 & 6.874 & 72.748 \\
\hline
\end{tabular}


Component 1 contributes more to total variance percentage. Its means that Indus Resource centre renders its efforts on enhancing the awareness of human rights and on its School projects. Component 2 is sustainable livelihood which includes poverty alleviation task and platforms for promoting hand made products. Component 3 includes education especially for girls and motivating parent to send their children especially girls to schools. Component 4 includes disaster recovery and rehabilitation Programs. Component 5 includes health programs.

On the basis of these five components, IRC is very much effective in fulfilling the needs of rural peoples. These five factors are very important components of a good life.So IRC should focus on these factors more in order to achieve $100 \%$ effectiveness because these components are contributed more in filling the gap of Government.

\section{Limitation}

This research tells about the Indus resource centrekhairpur Pakistan (NGO) performance and its findings are limited to the rural khairpur.Result and discussion of the research does not represent all non government organizations. The contribution of others NGOs may be different towards fulfilling the gap of government.

\section{References}

1. Bratton, M. (1989). Beyond community development. The political economy of rural administration in Zimbabwe .

2. Chitongo, L. (july 2013). The Contribution of NGO's to rural development: the case of catholic Relief services protecting vulnerable livelihood programme in Zimbabwe. Asian journal of Management sciences and education , 124-143.

3. Desai. (2005). NGO's gender mainstreaming and urban poor communities in Mumbai. Gender and Development, 9098.

4. Enyioko, N. c. (2012). Role of Non-Governmnetal organizations(NGO's) in rural development:A study of six listed NGO's in rivers state,Nigeria. Medonice Management and Research consulting limited , 1 to19.

5. Fowler, A. (1988). NGO's in Africa achieving comparative advantage in relief and micro development. IDS Discussion paper.institute of Development studies,Sussex , 249.

6. Grandvaux, Y. M., welmond, M., \& wolf, J. (2002). Evolving Partnerships: The role of NGO's in basic education in Africa. Washington: SARA(Support for analysis and research in Africa) project.

7. Kanipakam, D. (2014). The role of NGOs in rural economic development of India:A socio legal perspective. International Journal of Applied Research and studies , 1 to7.

8. Lewis, D., \& Kanji, N. (2009). Non Govermental organization and Development. london and New york: Routledge.

Lewis, D., \& Kanji, N. (2009). Non-Governmental organization and development. USA and Canada: Routledge.

10. Mudimu, G., \& Bernisten, R. (1987). Household and national food security in southern Africa. Department of Agriculture economics and extension UZ .

11. Nikkah, H. A., \& Redzuan, M. b. (2010). The role of NGO's in promoting empowerment for sustainable community development. J hum Ecol , 85to92.

12. Obot, D. I. (1989). Rural development programms of te DFRRI in cross river:A pessimistic view. Journal of the institute of Town planners, viii to ix.

13.Seidemann, S. B. (2011). Actual and potential roles of local NGO's in agriculture development in sub-saharan Africa. Quarterly journal of International Agriculture , 65to78.

14.Streeten, P. (1997). Non-Governmental organization and Development. Annals of the American Academy of political and social science, 193-210.

15. Talat, A., Quershi, S., \& Ali, H. (2004). Landlessness and Rural Poverty in Pakistan. The Pakistan Development Review .

16. Tufail, S. (2006). Role of NGOs in Pakistan. Pakistan Politics, current affairs, business and lifestyle .

17. Ulleberg, I. (2009-10). The role and imapct of NGO in capacity development. France: international institude for educational planning.

18. Willis, k. (2005). Theories and Practices of Development. Iondon: Routledge.

19. zikmund, w. G. (2000). Business Research Methods. 


\section{Author's Biography}

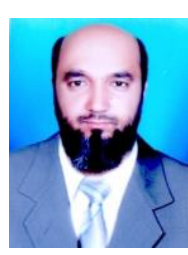

"Completed my MBA from Shah Abdul Latif University Khairpur, Sindh Pakistan in Finance and appointed as lecturer there in september 2004 and completed my M. Phil in Finance from IQRA University Karachi in 2010 and promoted as Assistant Professor, now recently submitted my Ph.D thesis for foreign evaluation from Shah Abdul Latif University Khairpur in Public finance under the supervision of Dr. Syed Munir Ahmed Shah". 